\title{
FREE SPEECH, FAIR TRIALS, AND FACTIONALISM IN UNION DISCIPLINE*
}

SEEKING to curb some of the abuses in the internal government of labor unions which had been uncovered by the McClellan Committee ${ }^{1}$ investigations, Congress appended Title I, the Bill of Rights of Members of Labor Organizations, ${ }^{2}$ to the Labor-Management Reporting and Disclosure Act of 1959.3 As introduced on the floor by Senator McClellan, the provisions of that title guaranteed certain rights of members against infringement by labor organizations; they were specifically amended during debate to insure that unions would be able to prescribe and apply reasonable rules to protect themselves against internal subversion of their institutional functions. ${ }^{4}$ Title I thus establishes a balance between the interest of members in democratic expression and the interest of labor unions in institution integrity. Yet it does not specify how that balance is to be struck; determinations of reasonableness must be made by the federal courts. Salzhandler $v$. Caputo ${ }^{5}$ was one of the first cases requiring interpretation of the balance-specifically, the balance within section 101 (a) (2), which guarantees freedom of speech and assembly to union members. ${ }^{6}$

* Salzhandler v. Caputo, 316 F.2d 445 (2d Cir.), cert. denied, 32 U.S.L. WEEK 3213 (U.S. Dec. 9, 1963).

The editors of the Journal wish to thank Miss Marguerite Schimpff, L.L.B. Yale, 1963, whose unpublished divisional paper "Brotherhood of Painters, Decorators and Paperhangers of America, AFL-CIO, District Council 9 of New York City: A Case Study" (on file, Yale Law School Library) has contributed substantially to our understanding and to this piece, and Professors Clyde W. Summers and Harry H. Wellington, of the Labor Law Division, who brought her paper to our attention.

1. The Committee on Improper Activities in the Labor Management Field, a specially created Senate select committee chaired by Senator McClellan.

2. 73 Stat. 522 (1959), 29 U.S.C. \$ 411 (Supp. IV, 1963).

3. 73 Stat. 519 (1959), 29 U.S.C. $\S \S 401-02,411-15,431-40,461-66,481-83,501-04$, 521-31 (Supp. IV, 1963).

4. 105 Cong. Rec. 6475 (1959). There was no Bill of Rights for Union Members in the Kennedy-Ives Bill of 1958, S. 3974, 85th Cong., 2d Sess. (1958) which passed the Senate and failed in the House of Representatives. Nor was any such provision included in the Kennedy-Ervin Bill, S. 1555, 86th Cong., 1st Sess. (1959) as reported out of the Senate Committee on Labor and Public Welfare.

Senator McClellan proposed the section as an amendment to the bill after it reached the floor of the Senate. 105 Cong. Rec. 6475 (1959). That amendment was passed on April 22, 1959; on April 25, the Senate modified the McClellan provision by approving an amendment thereto proposed by Senator Kuchel, which, among other changes, added the clause "subject to the organization's established and reasonable rules pertaining to the conduct of meetings" and the Proviso now found in $\$ 101$ (a) (2) of the act. Note 6 infra. See Rothman, Legislative History of the "Bill of Rights" for Union Members, 45 MrNw. L. Rev. 199 (1960).

5. 316 F.2d 445 (2d Cir.), cert. denied, 32 U.S.L. WeEK 3213 (U.S. Dec. 9, 1963).

6. Section $101(\mathrm{a})(2)$ reads:

FreEdon of SPEeCH AND AsSeMrbLx. - Every member of any labor organization shall have the right to meet and assemble freely with other members; and to express 
Solomon Salzhandler, as Financial Secretary of Local 442 of the International Brotherhood of Painters, Paperhangers, and Decorators of North America, ${ }^{7}$ became aware in the summer of 1960 of what he considered to be financial irregularities within the Local. In the autumn of that year, having evoked no response to complaints filed with the regular councils of the union, ${ }^{8}$ Salzhandler composed and distributed within the union a leaflet incorporating his suspicions and denouncing Isidore Webman, President and Business Agent of Local 442, on several minor counts, some specific and documented, others rather vague. ${ }^{9}$ His language was not always temperate: among other epithets, he labeled Webman a "petty robber," "most unworthy of any trust," and described what he thought to be "the cheapest petty act ever."10 Webman filed charges against Salzhandler with District Council No. 9, of which Local 442 was a part, complaining that his conduct violated sections of the Brother-

any views, arguments, or opinions; and to express at meetings of the labor organization his views, upon candidates in an election of the labor organization or upon any business properly before the meeting, subject to the organization's established and reasonable rules pertaining to the conduct of meetings; Provided, That nothing herein shall be construed to impair the right of a labor organization to adopt and enforce reasonable rules as to the responsibility of every member toward the organization as an institution and to his refraining from conduct that would interfere with its performance of its legal or contractual obligations.

73 Stat. 522 (1959), 29 U.S.C. § 411 (a) (2) (Supp. IV, 1963).

7. All background information on the Brotherhood of Painters, Decorators and Paperhangers and on the disciplinary proceedings involving Solomon Salzhandler have been taken from an unpublished divisional paper in the Yale Law School: Schimpff, Brotherhood of Painters, Decorators and Paperhangers of America, AFL-CIO, District Council 9 of New York City: A Case Study (1963) (Yale Law School Library).

8. Salzhandler complained to the General Executive Board of the International without response and claimed to have levied charges against Webman, whom he held responsible for the irregularities within District Council No. 9. The latter formality was denied by the District Council officers.

9. Brief for Appellant, Appendix, Exhibit “A," Salzhandler v. Caputo, 316 F.2d 445 (2d Cir. 1963). The alleged malpractices concerned a group of checks drawn on the Local's bank account. Two of the checks were supposed to have covered the salaries and expenses of Webman and the Local's late business agent, Max Schneider, both of whom were Local 442's delegates to the 1959 International Convention. One check for $\$ 800$ showed Webman as payee; the other for $\$ 375$ was written to "cash": both were endorsed by Webman and his wife. Salzhandler suggested in the pamphlet that Schneider never received his check. The Business Agent died in the spring of 1960 and Webman was appointed to fill the unexpired term. Alleged as well in the pamphlet was that the voting on a proposal to tax each member $\$ 2$ for a $\$ 1,000$ donation to Schneider's son was conducted "fraudulently and by deceit." There were also general accusations about tyrannical administration and slanderous epithets which Salzhandler claimed Webman had applied to union members.

10. Brief for Appellant, Appendix, Exhibit "A." Salzhandler v. Caputo, 316 F.2d 445 (2d Cir. 1963). The pamphlet continues: "Two widows were.refunded each $\$ 6$ for overpayment of dues. Two checks were issued to that effect. The petty robber had two friends sign their names and the chairman declared these two checks as contributions to the special tax for Michael Schneider. Photostats of checks enclosed." Ibid. 
hood's constitution prohibiting defamation, ${ }^{11}$ acts unbecoming an officer, ${ }^{12}$ acts detrimental to the union, ${ }^{13}$ and acts inconsistent with the responsibilities of a member. ${ }^{14}$ A trial board, appointed by Council President Caputo from among the members of District Council No. 9,15 found Salzhandler guilty as charged and suspended him from union activities for five years. After a series of raucous events, ${ }^{16}$ Salzhandler filed suit against Caputo in the District Court for the Southern District of New York under sections $102^{17}$ and $609^{15}$ of the LMRDA, asking nullification of the disciplinary proceedings, reinstatement to his local office, and damages. His suit was dismissed on its merits in March, 1962.19 The Court of Appeals for the Second Circuit reversed and

11. Constitution of the International Brotherhood of Painters, Decorators and Paperhangers of North America \$ $267(10)$.

12. Id. $\$ 267(5)$.

13. Id. $\$ 267(6)$.

14. $I d . \S 267(16)$.

15. Salzhandler argued that the trial board was biased against him because Webman and Caputo were supporters of Rarback, whom Salzhandler opposed, and were anxious to silence the latter during an election year. One of the Trial Board members, Jack Breen, was also alleged to be a political and personal enemy of Salzhandler. He also complained that the composition of the union trial board that heard his case did not comply with the union constitution. The constitution of the International Brotherhood of Painters, Decorators and Paperhangers of North America, $\$ 629(\mathrm{~b})$, establishes that the trial board shall consist of the executive board of the district council; $i d ., \$ 220$ (c) provides that the executive board shall be composed of the chief officers of the district council. None of the District Council No. 9 officers sat on Salzhandler's Trial Board, as District Council President Caputo had exercised his discretion under District Council No. 9 By-Laws, Article XIII \& 9 which allows him to appoint substitutes for any district officers who might be interested parties in the case before the trial board.

16. These events included Salzhandler's attempt to remain in office as Financial Secretary of Local 442 , criminal charges brought by the other officers to compel him to turn over the Local's books, a fist-fight at the meeting for nomination of officers, and a resultant suit by a Salzhandler supporter against Webman for assault and battery. See Schimpff, supra note 7, at 9.

17. Section 102 provides:

Any person whose rights secured by the provisions of this title have been infringed by any violation of this title may bring a civil action in a district court of the United States for such relief (including injunctions) as may be appropriate. Any such action against a labor organization shall be brought in the district court of the United States for the district where the alleged violation occurred, or where the principal office of such labor organization is located.

73 Stat. 523 (1959), 29 U.S.C. $\$ 412$ (Supp. IV, 1963).

18. Section 609 provides:

It shall be unlawful for any labor organization, or any officer, agent, shop steward, or other representative of a labor organization, or any employee thereof to fine, suspend, expel, or otherwise discipline any of its members for exercising any right to which he is entitled under the provisions of this Act. The provisions of section 102 [29 U.S.C. $\$ 412$ ] shall be applicable in the enforcement of this section.

73 Stat. 541 (1959), 29 U.S.C. § 529 (Supp. IV, 1963).

19. Salzhandler v. Caputo, opinion not reported (S.D.N.Y. 1962). The opinion appears in Defendants' Petition for Certiorari, p. 31, Caputo v. Salzhandler, No. 282, Oct. term 1963. 
granted Salzhandler the requested relief, construing section 101(a)(2) to preclude discipline for conduct such as his even in the presence of a union rule prohibiting libel and slander of officers. ${ }^{20}$

That decision seems sound in its result: given the context of Salzhandler's conduct, his treatment resembled more political suppression than punishment for defamation. President Webman and Financial Secretary Salzhandler were familiar and bitter factional combatants: Webman was a supporter of the incumbent administration; Salzhandler had been associated with an earlier Communist regime and had since been a vigorous foe of the leadership. ${ }^{21}$ And, although defamation had been the gravamen of the union's charges, Salzhandler's criticism was in no meaningful sense defamatory. However ungentlemanly his accusations may appear-at least by most standards of polite debate-gallantry was not the norm of political opposition within this particular arena of conflict. Although a strong union when negotiating with employers, the Painters, and especially District Council No. 9, have writhed with internal dissension and hostility for the last forty-five years. ${ }^{22}$ In the two year period preceding the Brotherhood's general elections of June, 1961, discontent was manifested in more than a dozen law suits against the union. Defamation was often alleged, the complaints suggesting that union meetings bristled with such epithets as "thieves, scabs, robbers, scabby bosses, bums, pimps, f-bums, and jail birds." 23 In such a setting town-meeting standards of fair criticism can have little application.

The Second Circuit approached the case differently. It found that Salzhandler's accusations, even if false and defamatory, could not be punished because they did not come within the terms of the proviso to section 101 (a) (2); his comments had not violated "the responsibility of every member toward the organization as an institution. ..."24 Protection of members' individual rights is paramount, the court reasoned, because the legislative history of the act made clear that union officials should not be allowed to exercise their dis-

20. Salzhandler v. Caputo, 316 F.2d 445 (2d Cir. 1963).

21. Since 1950 Salzhandler had also been a regular supporter of litigation against officers in the Rarback administration; two such cases are Waldman v. Ladisky, 101 N.Y.S.2d 87 (Sup. Ct. 1950) ; and Rubinow v. Ladisky, 198 Misc. 225, 97 N.Y.S.2d 526 (Sup. Ct. 1950). See Schimpff, supra note 7, at 7.

22. Gangsters and racketeers exploited the union during the 1920's and 1930's, their corruption breeding the discontent which opened the Brotherhood to Communist penetration in the late 1930's and domination during the war. In 1947 a Trotskyite faction under the direction of Martin Rarback took the leadership out of the grasp of the Communists, but was not of sufficient strength to prevent the union's being embroiled over the next six years in an incessant struggle for control. Only by the late 1950's was the Rarback group the firmly established administration of the Brotherhood, by which time disenchantment with the leadership was already widespread among the rank and file. See Schimpff, supra note 7, at 1-4.

23. Brief for Appellant, Appendix, Exihibit "A", Salzhandler v. Caputo, 316 F.2d 445 (2d Cir. 1963). See Schimpff, supra note 7 passim.

24. Labor-Mlanagement Reporting and Disclosure Act of 1959, $\$ 101$ (a) (2), 73 Stat. 522 (1959), 29 U.S.C. $\$ 411$ (a) (2) (Supp. IV, 1963). 
ciplinary powers "to silence criticism and punish those who dare to question and complain." ${ }^{25}$ Especially where financial malpractices may be involved, Congress sought to encourage hard questioning by the membership. ${ }^{28}$ The court relied upon this broad mandate to protect members' rights because it found union tribunals inherently incapable of "drawing the fine line between criticism and defamation"27 - a remark which seems directed more to their expected partiality than to their technical incompetence-and because it is impractical for federal courts to give every complaining union member a trial de novo. Thus the distinctions between criticism and defamation become "wholly immaterial,"28 because unenforceable, and the attention of the court is to be fixed upon whether the conduct of the member clearly violates his responsibility to respect the interests of the union.

Before the passage of the act, state courts did not look to the institutional interests of the union; in analogizing members' rights to first amendment protections, they usually found defamation not to be protected speech, and therefore a valid instance for union discipline. ${ }^{29}$ Even in the debates of Con-

25. Salzhandler v. Caputo, 316 F.2d 445 at 449 (2d Cir. 1963).

26. Id. at 450 . The court was probably alluding to section 501 of the Act, Fiduciary Responsibility of Officers of Labor Organizations, which, in section 501(b), authorizes members to sue union officials suspected of violation of their fiduciary obligations if the other union officials refuse to do so. Members can be reimbursed for expenses incurred in prosecuting the union's cause against the officer. 73 Stat. 535 (1959), 29 U.S.C. \& 501 (Supp. IV, 1963). See, Comment, Coninsel Fees for Union Officers under the Fiduciary Provision of Landrum-Grifin, 73 Y $\mathrm{AiE}$ L.J. 443 (1964).

27. 316 F.2d at 450 .

28. Id. at 451 .

29. Ames v. Dubinsky, 5 Misc. 2d 380, 70 N.Y.S.2d 706 (Sup. Ct. 1947). See also Shapiro v. Gehlman, 152 Misc. 13, 272 N.Y. Supp. 624 (Sup. Ct. 1934), rev'd, 244 App. Div. 238, 278 N.Y. Supp. 785 (1935), aff'd as modified sub nom. Shapiro v. Brennan, 269 N.Y. 517,199 N.E. 515 (1935).

The Supreme Court in Beauharnais v. Illinois, 343 U.S. 250 (1952), held that the protection of freedom of speech guaranteed in the first amendment to the Constitution does not extend to libel.

It has been well observed that such utterances are no essential part of any exposition of ideas, and are of such slight social value as a step to truth that any benefit that may be derived from them is clearly outweighed by the social interest in order and morality.

Id. at 256-57. The analogy of union members' rights to those guaranteed by the first amendment rests upon the argument, advanced by most labor law commentators, that since unions, as a form of industrial government derive much of their power from federal statutory protection, they should be limited in their authority to discipline members much as the Constitution places limitations on civil governments. See Kovner, The Legal Protection of Civil Liberties Within Unions, 1948 Wrs. L. Rev. 18; Witmer, Civil Liberties and the Trade Union, 50 YALE L.J. 621 (1941); Summers, Legal Limitations on Union Discipline, 64 HaRv. L. Rev, 1049, 1072-74 (1951).

For analogies of unions to civil governments, see Summers, Disciplinary Procedures of Unions, 4 IND. \& LAB. REL. REv. 15, 30 (1950) ; Williams, The Political Liberties of Labor Union Members, 32 Texas L. Rev. 826, 832 (1954); also see Taft, Democracy in Trade Unions, 36 Anr. Econ. Rev. (Papers \& Proceedings) 359 (1946). 
gress, the analogy to first amendment rights suggested that libel and slander could be prohibited with reasonable rules. ${ }^{30}$ But the act was not written in such terms. Speech which is libelous does not necessarily have any impact upon the union. Unless it had such impact, it could not interfere with the union's legal and contractual obligations or contravene the member's responsibility to the union as an institution, the proviso's grounds for discipline. Section 101(a) (2) must therefore be read to bar union rules which prohibit all defamation of union members and officers: libelous speech which does not institutionally affect the union is-by the terms of the act-protected. Yet even when the union is institutionally affected, the proviso requires that the union rule prohibiting the criticism be "reasonable," no matter how vital the

Nonetheless, courts freely manipulated the analogy, and most other theories, constitutions, and facts to protect the members' right to speak against union suppression, using the contract theory as an umbrella for protecting speech, Polin v. Kaplan, 257 N.Y. 277, 177 N.E. 833 (1931) ; Irwin v. Possehl, 143 Misc. 855, 257 N.Y. Supp. 597 (Sup. Ct. 1932). Courts have traditionally protected speech either by finding procedural defects in the disciplinary proceedings, Smith v. International Printing Union, 190 S.W.2d 769 (Tex. Civ. App. 1945), or by free construction of union rules, Walsh v. Reardon; 274 Mass. 530, 174 N.E. 912 (1931), and Johnson v. Local 971, Bhd. Carpenters, 52 Nev. 400, 288 Pac. 170 (1930).

Fitfully, though, a doctrine of "fair criticism" emerged. "Fair criticism is the right of members of a union, as it is the right of every citizen. A provision of a union constitution which would suppress protests of members against actions of their officers which such members regarded as improper or opposed to their best interests, would be illegal and unenforcible [sic]." Schrank v. Brown, 192 Misc. 80, at 83, 80 N.Y.S.2d 452, at 455 (Sup. Ct. 1948). As this right became fixed by judicial recognition, the unions' authority to discipline for libel and slander was correspondingly circumscribed. Taking cognizance of the realities of union politics, some courts began to provide protection for substantially true even though defamatory criticism, Shapiro v. Gehlman, 244 App. Div. 238, 278 N.Y. Supp. 785 (1935), reversing 152 Misc. 13, 272 N.Y. Supp. 624 (1934), aff'd as modified sub nom. Shapiro v. Brennan, 269 N.Y. 517, 199 N.E. 515 (1935), especially if uttered in the heat of a bitter political campaign. Reilly v. Hogan, 32 N.Y.S.2d 864 (Sup. Ct. 1942), aff'd, 264 App. Div. 855, 36 N.Y.S.2d 423 (1942) (memorandum decision). Union discipline was sometimes nullified as unduly harsh for a minor indiscretion, such as to suggest that it was politically motivated punishment. In Reilly v. Hogan, supra, the leader of an opposition faction charged during a bitter election campaign that the incumbents were using union funds to aid the Abraham Lincoln Brigade during the Spanish Civil War, and was expelled from the union for slandering officers. In ordering his reinstatement the court took note of the context of the statement, emphasized that it was a minor charge with little potential for disruptive impact, and suggested that so harsh a penalty indicated some political motivation behind the discipline. Moreover, courts have regularly held that discipline must be in "good faith" if punishment is to be inflicted. Eschman v. Huebner, 226 III. App. 537 (1922) ; Kinane v. Fay, 111 N.J.L. 553, 168 Atl. 724 (Sup. Ct. 1933).

30. 105 Cong. Rec. 6472, 6478, 10902 (1959) (Remarks of Sen. McClellan); 105 Cong. Rec. 6726 (1959) (Remarks of Sen. Javits); 105 Cong. Rec. 6719 (1959) (Remarks of Sen. Kuchel).

There is no reason to interpret the congressional amalogy so rigidly as to preclude the reasonable exceptions to protected speech in the union context being quite different from those in other settings. It was recognized that the impact of certain speech varies with its audience. 105 Cong. Rec. 15680 (1959) (Remarks of Rep. Celler). 
union function which the rule purports to protect. It is unclear by what standard of reasonableness union rules are to be measured, the permissive standard of rationality often used in evaluating state economic regulation or a more stringent standard of direct relevancy to immediate danger as is generally considered appropriate to first amendment issues. What is clear is that the primary purpose of Congress to guarantee members' political rights requires that, to be reasonable, a rule must always leave available some means for bringing relevant critical truth to union members.

Some decision-maker is required to make these difficult determinations as to whether the criticism, true or defamatory, affects the union institutionally, and whether the rule prohibiting it is reasonable. Two observations within the Salzhandler opinion indicated how difficult a problem satisfying such a requirement may be. Union tribunals, the court said, cannot be expected to be impartial, ${ }^{31}$ and in union discipline cases it is impractical for federal courts to hold trials de novo. ${ }^{32}$ If these observations are valid, then no disinterested and competent decision-maker can ever be found to distinguish between protected and punishable criticism, even when the union is clearly affected. Presumably, then, a union tribunal would not be sufficiently disinterested to be allowed to determine whether a member's responsibility to the organization as an institution had been violated if he had accused a bargaining agent of collusion with management during a period of precarious contract negotiation. To permit adjudication by such a tribunal might threaten the substantive rights and protections of section 101 (a) (2). Furthermore, to do so might constitute a denial of the "fair hearing" guaranteed by section 101 (a) (5).33 Yet a trial de novo in a federal court would still be impractical, and if the union is to be denied the authority to discipline for such conduct, it is stripped of its shield against crippling attacks upon its vital functions. For such untimely accusations, by undermining the confidence of the membership in its negotiator, can subvert a collective bargaining effort, perhaps the most basic function of organized labor. Just as serious might be a racially oriented assault upon the leadership of a young and struggling union in Mississippi by an agent of the boss, or widespread publication of a false allegation of Communism or corruption among union officers in the midst of a prolonged strike. The ability to undermine, in good faith or in bad, the confidence of members, employers, and public in a union leader can be the ability to destroy the union itself as a bargaining agent, as a private enforcer of contracts, and thus as

31. Salzhandler v. Caputo, 316 F.2d 445, 450 (2d Cir. 1963).

32. Ibid.

33. Section 101(a) (5) provides:

Safeguards Against Improper Disciplinary Action. - No member of any labor organization may be fined, suspended, expelled, or otherwise disciplined except for nonpayment of dues by such organization or by any officer thereof unless such member has been (A) served with written specific charges; (B) given a reasonable time to prepare his defense; (C) afforded a full and fair hearing.

73 Stat. 522 (1959), 29 U.S.C. § 411(a) (5) (Supp. IV, 1959-1963). 
a participant in the process of industrial democracy. ${ }^{34}$ Discipline has been the union's traditional means of protection against such internal threats to its institutional welfare ${ }^{35}$ and Congress opted for its preservation in passing the proviso to section 101 (a) (2).

The problem of the lack of an appropriate decision-maker when injury to the union is at issue is not limited to the case of hostile criticism; it pervades the whole of section 101(a) (2). A member who incites his fellows to leave the picket line may damage the union as an institution no less than one who disrupts collective bargaining. Yet if union tribunals are biased, they are as incapable of drawing the "thin and tenuous line" between strike-breaking and a timely call for a return to work as they are to distinguish between political

34. Summers, Disciplinary Powers of Unions, 3 IND. \& LAB. REL. REv. 483, 490 (1950). The ILGWU was very nearly destroyed by such tactics; see SEIDMAN, The Needle Trades (1942). Other unions have also suffered paralysis from internal factionalism owing to Communist subversion; see Schnerder, The Workers' (ConrMunist) Party in American Trade Unions (1927). The same pernicious forms of factionalism may be used by groups at the other end of the political spectrum, such as the Anti-Communist Association of Catholic Trade Unionists; see Levenstetn, Labor Today and TOMrorrow 163-64 (1945).

35. See Taft, Judicial Procedure in Labor Unions, 59 Q.J. EcoN. 370, 377-81 (1945). Almost every union has made provision in its constitution protecting itself, its leadership, and its members from such defamation. An AFL-CIO study made in preparation for the appeal of the Salshandler case to the Supreme Court showed 125 of the 152 affiliated international unions had clauses in their constitutions which either expressly or by necessary implication made slander, libel or defaming of an officer a punishable offense. All but 3 of the 152 had general provisions under which such behavior might be punished. Defendants' petition for Writ of Certiorari at 6-7. See also Summers, Disciplinary Powers of Unions, 3 IND. \& LAB. REL. REV. 483, 498 (1950).

Unions have a heritage of strife, both internal and with other groups, which has required the kind of constant vigilance to attack and subversion that provokes hypersensitivity to their own security. "It [the union] is primarily a contending and combatitive organization which needs to be ever ready to engage in battle for vital economic and political stakes, often for survival; to marshal all it possesses and more, including its members' enthusiasm, loyalty and self interest." Hardman, Comment, in Symposium on THE Labor-Managearent Reporting and Disciosure ACT of 1959 347, 350 (Slovenko, ed. 1960).

For a background or the heritage of strife of the labor movement and expansion of the war analogy, See Aaron, Unions and Civil Liberties: Claims vs. Performance, 53 Nw. U.L. Rev. 1, 2-3 (1958), and Summers, Disciplinary Powers of Unions, 3 IND. \& LAB. ReL. Rev. 483, 489 (1950). See also Summers, Disciplinary Procedures of Unions, 4 IND. \& LaB. ReL. Rev. 15, 30 (1950).

Not only their heritage of strife, but also their tradition of beneficent paternalism conduces to union leadership's interpreting dissension and criticism, not as expression of democratic rights, but as a threat to the institution itself. Kovner, The Legal Protection of Civil Libcrties Within Unions, 1948 WIs. L. REv. 18, 19. Constitutional provisions, "reasonable rules," thus can be misapplied to suppress opposition, perverting in that instance the legitimate function of the device. The provision itself, though, is no less valid, even necessary, as an institutional safeguard against scurrilous attack. It is no less a reasonable rule. Summers, Disciplinary Powers of Unions, 3 IND. \& LAB. ReL. Rev. 483, 512 (1950). 
opposition and an institutional attack. And the Salzhandler caveat that trials de novo in federal courts are impractical would also apply to this determination. Are unions therefore to be denied the right to discipline for such conduct? And, similarly, would a union be allowed to distinguish between free assembly and dual unionism, or between peaceful protests and obstructionism? Yet the unions' need for discipline as a means of self-preservation should not compel courts to permit biased union tribunals to mete out that discipline in abrogation of the intended protection of members' rights-including protection of their right to fair proceedings.

If the balance of members' rights and the institutional welfare of organized labor inherent within section 101(a) (2) is to be preserved, then a decisionmaker must be found to investigate with some sophistication the particular circumstances surrounding the member's conduct-to determine whether his responsibility to the union was violated and whether the rule under which he was disciplined was reasonable. The range of relevant variables in any case of union discipline is enormous. Any examination into context has to take account of such factors as the nature of the act: was it valid criticism or malicious slander, intended to improve or disrupt, a serious accusation or a petty complaint? Equally important is the timing of the conduct: was it an attack in the midst of a serious challenge to the organization, in a period of contract negotiation, of a membership drive, during a strike, or was the opposition manifest during an internal election or at a time of relative institutional stability? At whom was the charge directed, and who was likely to be damaged by it, the particular leadership, or the union itself? Obviously relevant here is the kind of union in which the act took place: was it a beleaguered coterie of organizers in Alabama or a firmly entrenched organization in Manhattan? The history and reasonable expectations of the members of the particular union could be relevant: has the government of the union been responsibly democratic, reasonably autocratic, or cynically dictatorial ?30 Was the disciplined speech typical of ordinary debate? Certainly an identification of the participants or the audience involved would be required: whether the audience to a scathing attack on the leadership was a meeting of a local or the general public, or whether the participants in an opposition political clique were all loyal members or directed and financed by an outside interest, could be determinative. In some cases the actual impact of the conduct, in most instances the impact reasonably to be expected, should be weighed.

Seventy years of experience of judicial involvement in internal union disputes strongly suggests that courts are unable to make so detailed an investigation of the relevant context of a member's conduct and to develop standards of reasonable behavior from that context. ${ }^{37}$ The inquiries inevitably to be made

36. A determination which obviously would not be aimed at prejudicing the outcome, but only relevant for reconstructing the setting in which the disputed conduct took place.

37. Several approaches to the problem of standards for distinguishing between protected and punishable conduct within labor unions have been attempted, each requiring inquiry into the facts of a case in varying degrees of detail. None of them has been con- 
are particular and complex problems of fact; reasoned distinctions necessitate a specialized understanding of the internal operations of the union involved.

sistently applied, and most have been undermined by the multiplication of exceptions and qualifications. The courts have manipulated these theories and rules without articulating their motives, so that their precedential value has been eroded.

Courts intervened originally on a contract theory interpreting union constitutions as contracts between union and members, defining duties and privileges, the means of securing them, and the conditions under which they will be lost. Courts adopting this theory insisted that members be disciplined only for conduct prohibited by, and in conformity with procedures spelled out in union constitutions, but refused to evaluate the procedure provided for. For a classic statement see Polin v. Kaplan, 257 N.Y. 277, 281-82, 177 N.E. 833,834 (1931).

Courts which have strictly applied the contract theory seem unconcerned that constitutions were "contracts" which could be amended by one party only, in fact, were "contracts" in which only one party was identified. At their best, they are contracts of adhesion at their worst. See, Wellington, Union Dentocracy and Fair Representation: Federal Responsibility in a Federal System, 67 Y ALE L.J. 1327, $1346-47$ (1958); Summers, Legal Limitations on Union Discipline, $64 \mathrm{HARv}$. L. REv. 1049, 1055 (1951); Summers, The Law of Union Discipline: What the Courts Do in Fact, 70 YaLE L.J. 175, 180 (1960). Where the custom and practice within a union are quite different from the procedures set out in the constitution, these courts have required strict adherence to the latter, see Harris v. National Union of Marine Cooks and Stewards, 98 Cal. App. 2d 733, 221 P.2d 136 (1950), even where the procedures complained of were fairer: Rodier v. Huddell, 232 App. Div. 531, 250 N.Y. Supp. 336 (1931); Simons v. Berry, 240 N.Y. 463, 148 N.E. 636 (1925) ; Tesoriero v. Miller, 74 N.Y.S.2d 145 (Sup. Ct. 1947).

On the other hand, the vagueness of many union constitutions has been naturally conducive to the kind of judicial interpretation which is in fact the imposition of judicial standards. "Ambiguous provisions were interpreted to conform to judicial policies, gaps were filled with judge-made law, and ambiguities or gaps were found in the most clear and complete clauses." Summers, American Legislation for Union Democracy, 25 Mod.L. REv. 273, 280 (1962). In time some courts even more directly intervened to excise constitutional provisions as "contrary to public policy," or "contrary to natural justice." Schneider v. Local 60, United Plumbers, 116 La. 270, 40 So. 700 (1905) ; Blek v. Wilson, 145 Misc. 373, 259 N.Y. Supp. 443 (Sup. Ct. 1932), rev'd on other grounds, 262 N.Y. 253, 186 N.E. 692 (1933). Thus while ostensibly applying the contract theory, courts sometimes ignore the "contract" or fashion it to their own purposes.

Most state courts require of union proceedings only that there have been substantial evidence to support the union tribunal's findings of fact. See Pfoh v. Whitney, 43 Ohio L. Abs. 417, 62 N.E.2d 744 (Ohio App. 1945). "It is not for this court to reexamine the evidence in order to see whether it would have arrived at the same conclusion as did the Trial Board." Rosen v. District Council 9, Brotherhood of Painters, 198 F. Supp. 46, 49 (S.D.N.Y. 1961). But that standard, too, has been distorted as courts inquired more searchingly into the real motivations for disciplinary action. Bush v. Internat'l Alliance of Theatre Stage Employees, 55 Cal. App. 2d 357, 130 P.2d 788 (1942) ; Blek v. Wilson, 145 Misc. 373, 259 N.Y. Supp. 443 (Sup. Ct. 1932), rev'd on other grounds, 262 N.Y. 253, 186 N.E.692 (1933). "Close examination of all other cases [than those involving discipline of Communists] ... makes clear that the courts normally reweigh the evidence, substituting their own evaluation of the facts for that of the union tribunal." Summers, The Law of Union Discipline: What the Courts Do in Fact, 70 YaLE L.J. 175, 185 (1960).

Frustration with these Janus-like principles finally led the New York courts to conclude in Madden v. Atkins, 4 App. Div. 2d 1, 162 N.Y.S.2d 576 (1957), aff'd as modified, 4 N.Y.2d 283, 174 N.Y.S.2d 633, 151 N.E.2d 73 (1958), that an extensive and careful 
Federal courts lack the time, resources, experience, and expertness to make such inquiries and draw the necessary distinctions. Moreover, whether or not federal courts are technically competent to handle these difficult factual issues, trials de novo would not be in harmony with the congressional option in favor of minimum intrusion of government into the internal affairs of unions. ${ }^{38}$ Emphasis in the act upon union initiative, union rule-making, and union self-government belies any solution which would leave federal courts as the only forum for valid disciplinary proceedings, even in so sensitive an area as political rights of members. What is required is a solution which recognizes the primacy of union self-government, and yet insures that self-government will not undermine the very rights which the act was written to protect.

Because of the difficulty faced by courts in appreciating the subtleties of the context of a member's conduct and the desirability of resolution of internal disputes by the union itself, the question of bias within union judicial systems merits close scrutiny. Of course, absolute impartiality can never be expected. Decision-makers will always possess preferences for particular policies, such as a predisposition in favor of internal order at the expense of free expression,

inquiry into the particular context of the conduct was required to determine whether union discipline would be sustained. Union officers, the courts declared, must expect criticism and other opposition through "traditionally democratic means," Madden v. Atkins, 4 N.Y.2d 283, 293-94, 174 N.Y.S.2d 663, 640-41, 151 N.E.2d 73, 78 (1958). That a member in the midst of a bitter political fracas transcends the bounds of veracity in some relatively minor way will not justify his discipline, even though the unity of the union be temporarily disrupted. Madden v. Atkins, 4 App. Div. 2d 1, 16-17, 162 N.Y.S.2d 576, 590-92 (1957), and 4 N.Y.2d 283, 293, 174 N.Y.S.2d 633, 640, 151 N.E.2d 73, 78 (1958). The court examined the total context of the alleged breach to determine whether libel was being punished, which is proper, or criticism was being repressed, which is not. Madden v. Atkins, 2 App. Div. 2d 1, 17, 162 N.Y.S.2d 576, 591-92 (1957), aff'd as modificd, 4 N.Y.S. 2d 283, 174 N.Y.S. 2d 633, 151 N.E.2d 73 (1958).

Professor Summers has suggested that the New York courts in Madden were actually articulating a course already long pursued silently, albeit clumsily, by them and by other state courts. Summers, The Law of Union Discipline: What the Courts Do in Fact, $70 \mathrm{Y}_{\mathrm{ALE}}$ L.J. 175, 196 (1960). Professor Summers has also said elsewhere that section 101 (a) (2) of the Act ". . . guaranteeing freedom of speech and assembly, made articulate the protection which a few courts had declared but many had in fact given." Summers, American Legislation for Union Demacracy, 25 MoD. L. REv. 273, 282 (1962). Very few state courts, though, have handled the necessary inquiries and balancing of factors as well as did the courts in Madden; very few federal courts could be expected to do so in the future.

38. Pervading the legislative history of the act are expressions of faith in the national commitments to economic and social pluralism. This fundamental notion, that a free society is secured by a flourishing of independent agencies each self-regulating within its own area of competence, was understood in Congress to imply the minimization of official intervention in the affairs of private organizations. These complementary policies are emphasized at all stages of the legislative history of the act, usually in the form of "the desirability of minimum intervention by government" and that "great care should be taken not to undermine union self-government." See the Report of the Senate Committee on Labor and Public Welfare accompanying S. 1555, the basis for the Labor-Management Reporting and Disclosure Act of 1959, S. Rep. No. 187, 86th Cong., 1st Sess. at 7 (1959), and 105 Cong. Rec. 6476 (1959) (Remarks of Sen. McClellan). 
the natural preference of any arm of a socially militant organization. But more serious is result-oriented bias toward personalities: whether prejudice for or against individual officers or members, or partiality for a particular regime or opposition group, these attitudes pervade systems of union discipline, precluding the rendering of equal attention and regard to all the parties appearing before them. Such bias is in many cases obvious, as where a member is tried by the complaining officers whom he criticized, ${ }^{39}$ or by their relatives, ${ }^{40}$ or by an executive board appointed by such officers, ${ }^{41}$ or by other members who owe appointments or other favors to them. ${ }^{42}$ Even when bias is less blatant, it may be inherent in cases under section 101(a) (2). Most discipline "cases litigated in the courts, especially those involving free speech, spring from internal factional struggles which often encompass the entire active membership. Any tribunal composed of union officials will probably be partial to the officials' political allies; ${ }^{43}$ a specially elected committee is just as likely to be dominated by one faction or the other ${ }^{44}$ and a trial by the whole local tends to be determined less on the merits of the case than on the strength of the factions. ${ }^{45}$ Even selecting trial boards by drawing lots may not insure that they are free from bias. ${ }^{40}$ Finally, appeals to international presidents and

39. Coleman v. O'Leary, 58 N.Y.S.2d 812 (Sup. Ct. 1945), appeal dismissed, 269 App. Div. 972, 58 N.Y.S.2d 358 (1945).

40. Koukly v. Canavan, 154 Misc. 343, 277 N.Y. Supp. 29 (Sup. Ct. 1935).

41. Barry v. Frascona, 28 L.R.R.M. 2480 (N.Y. Sup. Ct. 1951).

42. Madden v. Atkins, 4 App. Div. 2d 1, 162 N.Y.S.2d 576 (1957), aff'd as modified, 4 N.Y.2d 283, 174 N.Y.S.2d 633, 151 N.E.2d 73 (1958).

43. In French v. Association of Master Painters (N.Y. Sup. Ct. 1961), the executive committee of the District Council No. 9 did not sit as the trial board because of interest in the case, which involved a dispute between the district council and a local. District Council President Caputo also disqualified himself from appointing a substitute trial board, as he was authorized to do under the council by-laws. Instead the delegates to the district council elected the trial board from among their number, but the court recognized that these officials were no less interested in the dispute than the officers themselves. Moreover, the court noted that such a trial board, elected after the dispute had achieved wide notoriety and discussion, could hardly be expected to possess the necessary disinterest.

44. In Madden v. Atkins, 4 App. Div. 2d 1, 162 N.Y.S.2d 576 (1957), aff'd as modified, 4 N.Y.2d 283, 151 N.E.2d 73, 174 N.Y.2d 633 (1958), three of the seven members elected to the trial committee were paid employees of the union, owing their jobs to the officers who had been criticized by the accused; a fourth judge had prosecuted charges against a member of the same opposition faction for a similar activity. Doubts as to the impartiality of the trial board were sufficient to discredit the disciplinary proceedings.

45. In Dragwa v. Federal Labor Union, 136 N.J. Eq. 172, 41 A.2d 32 (1945), the accused had been charged with conduct unbecoming a union member for allegedly telling the factory forewoman that the union was putting pressure on her to slow her work; it was commonly known that the accused was resented by other union members for working "too fast." The court, nonetheless, was unable to find any bias in her expulsion from the union after a trial before the whole local. See also Summers, Disciplinary Procedures of Unions, 4 IND. \& LAB. REL. REV. 15, 25 (1950).

46. Fitipaldi v. Legassie, 7 App. Div. 2d 521, 184 N.Y.S.2d 226 (1959); Harris v. National Union of Marine Cooks, 98 Cal. App. 2d 733, 221 P.2d 136 (1950). 
councils, though generally permitted, cannot be expected to cure political infections in trials below, as international officers are no more immune to factional politics than those of the locals. ${ }^{47}$

Bias so pervasive should give serious concern to those charged with implementing the Bill of Rights for Union Members. Any system in which the disciplinary process is invoked by those who in reality try the case is an anathema to responsible self-government. ${ }^{48}$ Without a truly independent union judiciary experienced and concerned with procedural safeguards, it will be difficult to attain that respect by the membership and the community for internal agencies and procedures which is indispensable for effective union selfgovernment. Such respect is vital within labor unions, where the disciplinary process not only provides an opportunity for both catharsis by frustrated and aggrieved members but also educates in the ways of democracy. In unions, the function of imparting a sense of justice having been done may be as important as that of imparting justice itself. ${ }^{49}$

However pervasive and contaminating partiality within union tribunals may be, state courts faced with challenges to union disciplinary proceedings have not adopted so comprehensive an analysis of the problem, but have sought specific proof of partiality in each case. When obvious, they have discredited partial tribunals and nullified the results of their proceedings. ${ }^{50}$ But courts

47. See Fish v. Huddell, 51 F.2d 319 (D.C. Cir. 1931) ; but contra Hall v. Morrin, 293 S.W. 435 (Mo. App. 1927), where a member was convicted of slandering international officers by a tribunal consisting of the international president and another officer. The court relied mechanically on the exhaustion of remedies rule even though the member's internal appeal would have been to the international executive board, whom he had allegedly slandered.

48. The usual union disciplinary procedure is that a trial board-consisting either of the union's executive board, members appointed by the president or elected by the local, usually five to seven in number-hears the case after charges have been filed in writing and timely notice given to the accused to prepare to defend himself. Each side may occasionally select counsel from among the membership, and each may present evidence and sometimes cross-examine witnesses. The trial board reaches a verdict by majority vote and reports to the next meeting of the local, which may accept, reject, or amend the report by vote of varying numbers of required members, and then chooses the appropriate penalty or relief. As a rule, either side may appeal from the local's decision to the interrational president, executive board, or convention. See Taft, Judicial Procedure in Labor Unions, 59 Q.J. Econ. 370, 381-84 (1945) ; Summers, Disciplinary Procednes of Unions, 4 IND. \& LaB. ReI. REV. 15, 17 (1950).

49. See Oberer, Volnntary Impartial Review of Labor: Some Reflections, 58 MIICH. L. Rev. 55 (1959); Steiber, Oberer \& Harrington, Union Dencocracy and Public Review (Center for the Study of Democratic Institutions, 1960).

Injustice to an individual member is apt to undermine confidence on the part of the other members as well as society at large, and tend to the destruction of the organization....

Blek v. Wilson, 145 Misc. 373, 377, 259 N.Y. Supp. 443, 448 (Sup. Ct. 1932), rev'd on other grounds, 262 N.Y. 253, 186 N.E. 692 (1933).

50. Coleman v. O'Leary, 58 N.Y.S.2d 812 (Sup. Ct. 1945), appeal dismissed, 269 App. Div. 972, 58 N.Y.S.2d 358 (1945) ; Koukly v. Canavan, 154 Misc. 343, 277 N.Y. Supp. 28 (Sup. Ct. 1935). 
have often found bias as elusive as judicial principles with which to detect it; then they tend to be less candid. When courts have thought the imposition of discipline by a union tribunal to have been politically motivated or simply unfair, but have been unable to isolate proof of partiality, they have selectively applied standards borrowed from criminal and administrative law to void the proceedings. .1 Such standards-timely notice, right to face and cross-examine accusers, presumption of innocence-do provide some guidance in determining the requisites of a fair hearing. But their selective application ${ }^{52}$ has permitted

51. Most state courts attempted, somewhat erratically, to impose minimum procedural requirements upon disciplinary proceedings. Summers, The Law of Union Discipline: What the Courts Do inr Fact, 70 Yale L.J. 175 (1960). In the absence of statutory authorization they justified their imposition on grounds of public policy, or "due process of law." See Ames v. Dubinsky, 5 Misc. 2d 380, 70 N.Y.S.2d 706 (Sup. Ct. 1947) ; Bricklayers' Union v. Bowen, 183 N.Y. Supp. 855, 859 (Sup. Ct. 1920); Sloan v. Braun, 20 Misc. 2d 204, 206, 191 N.Y.S.2d 213, 215 (Sup. Ct. 1959).

In over two-thirds of the cases in which courts have granted relief to a disciplined union member, some flaw in the union's trial procedure has been cited as the reason for invalidating the proceedings. Summers, The Law of Union Discipline: What the Coutrts Do in Fact, 70 Yale L.J. 175, 200 (1960). Among the prerequisites for fair procedure, the absence of which will cause most courts to nullify the discipline are: adequate and timely notice, Holmes v. Brown, 146 Ga. 402, 91 S.E. 408 (1917); sufficient opportunity to prepare defense, Walsh v. International Alliance of Theatrical State Employees, 22 N.J. Misc. 161, 37 A.2d 667 (Ch. 1944); full opportunity to present evidence, Cotton Jammers' Ass'n v. Taylor, 23 Tex. Civ. App. 367, 56 S.W. 553 (1900) ; full opportunity to know evidence against him, Armant v. Cannon Employees Ass'n, 11 LAB. REL. REP. 752 (Cal. Super. Ct. 1942) ; presumption of innocence, Harmon v. Matthews, 27 N.Y.S.2d 656 (Sup. Ct. 1941) ; trial at time and place convenient to the accused, Fales v. Musicians' Protective Union, 40 R.I. 34, 99 Atl. 823 (1917) ; freedom from double jeopardy. Reub v. Rehder, 24 N.M. 534, 174 Pac. 992 (1918).

52. Occasionally a court will admit its real rationale, Jose v. Savage, 123 Misc. 283, 284, 205 N.Y. Supp. 6, 7 (Sup. Ct. 1924). Usually, though, courts are not so candid in admitting that they protect the exercise of political rights by finding technical violations of procedure with which to invalidate the disciplinary proceedings. Scivoletti v. Leckie, 148 N.Y.S.2d 50 (Sup. Ct. 1955), aff'd as modified, 4 App. Div. 2d 773, 165 N.Y.S.2d 529 (1957); the same process is employed by finding hidden weaknesses of evidence, Fitipaldi v. Legassie, 7 App. Div. 2d 521, 184 N.Y.S.2d 226 (1959), or Koukly v. Canavan, 154 Misc. 343, 277 N.Y. Supp. 28 (Sup. Ct. 1935). "In short, the courts have not limited their power to interpret procedural provisions. That power is not exercised according to any abstract formula, but is used as a handy tool to protect individual members from discipline which the courts feel is unfair, without just cause, or unduly severe." Summers, Legal Limitations on Union Discipline, 64 HARv. L. Rev. 1049, 1078-79 (1951). "[T] he deviation tolerated depends largely on the judicial tolerance of the offense punished." Summers, The Law of Union Discipline: What the Courts Do in Fact, 70 YaLE L.J. 175, 201 (1960).

Courts' interest in union members' political rights seems to disappear when these rights become the vehicle of certain activities, such as dual-unionism. In Margolis v. Burke, 53 N.Y.S.2d 157 (Sup. Ct. 1945), a local president who applied for a charter in a rival union was summarily expelled without notice, and without a hearing. The court dismissed his objections, finding that the union acted in substantial compliance with the constitution, and that the plaintiff had "unclean hands." The courts have shown the same lack of interest for the political and procedural rights of members disciplined for Com- 
the basic problem of biased tribunals to be avoided and obscured. Too often courts have "felt" partiality and fixed upon some unimportant procedural slipup on which to pin the invalidation of the proceedings. ${ }^{53}$ As a result of relying upon such inconsequential factors, courts have even occasionally ruled themselves into contradictory circles. ${ }^{54}$

Specific proof of bias should not, however, be required in each case. For the disqualification of a tribunal for bias can be viewed as the obverse of the presumption of impartiality which normally attends the oath of judicial office; as such, it is too presumptive in nature. ${ }^{55}$ To disqualify for bias, it should be sufficient that some characteristic of the tribunal, such as the manner in which it has been appointed, reveals a significant potential of partiality. Rather than expressing disapproval of a particular tribunal, the decision to disqualify should reflect the judgment that the circumstances present an unacceptable likelihood that tribunals so constituted will be biased. ${ }^{56}$ The realities of union

munist activities and associations. Ames v. Dubinsky, 5 Misc. 2d 380, 70 N.Y.S.2d 706 (Sup. Ct. 1947). The International Brotherhood of Painters, Decorators, and Paperhangers of America, especially District Council No. 9 has been involved in several such cases. Weinstock v. Ladisky, 197 Misc. 859, 877, 98 N.Y.S.2d 85, 102 (Sup. Ct. 1950); French v. Ladisky, 194 Misc. 549, 78 N.Y.S.2d 690 (Sup. Ct. 1947), aff'd, 274 App. Div. 765,80 N.Y.S.2d 728 (1948). In the latter case, a vociferous political leftist complained that he had been denied due process at several points during the disciplinary proceedings in which he was suspended from union activities for three years for allegedly having permitted the use of spray guns. His suit was dismissed for failure to exhaust union remedies; when he completed his internal appeals, to no avail, he filed again in the New York courts, only to have his case dismissed; his first suit was held res judicata.

53. Reilly v. Hogan, 32 N.Y.S.2d 864, 869 (Sup. Ct. 1942), aff'd, 264 App. Div. 855, 36 N.Y.S.2d 423 (1942). See also note 52 stipra.

54. The New York courts were trapped into such a contradiction in the cases of Shapiro v. Gehlman, 244 App. Div. 238, 278 N.Y. Supp. 785 (1935), reversing 152 Misc. 13, 272 N.Y. Supp. 624 (1934), aff'd as modified, 269 N.Y. 517, 199 N.E. 515 (1935), and Cohen v. Rosenberg, 262 App. Div. 274, 27 N.Y.S.2d 834 (1941), aff'd, 287 N.Y. 800, 40 N.E.2d 1018 (1942). Faced in Shapiro with the complaint of an alleged slanderer of union officers that his trial was not in compliance with the union constitution, the court disregarded the fact that a constitutionally composed tribunal would have included the slandered officers and nullified the discipline on the contract theory. A few years later the same court held in Cohen v. Rosenberg, supra that the proceedings of a trial board, organized in exact compliance with the union constitution and thus consisting of officers allegedly libeled by the plaintiff, were void on their face for bias.

55. For discussion of the applicability of these presumptions to statutorily constituted boards regulating professions and trades, see the options in State Board v. Thrift-D-Lux Cleaners, 40 Cal.2d 436, 245 P.2d 29 (1953) and in Blumenthal v. Board of Medical Examiners, 57 Cal. 2d 228, 368 P. 2d 101 (1962).

56. The ramifications of disqualifying a union tribunal for partiality are quite different from those of a state or federal court's disqualifying itself because of personal interest in the result. Faced in Evans v. Gore, 253 U.S. 245 (1920) with the question as to whether a tax on the income of federal judges violates the constitutional protection of federal judges' compensation from diminution, the Supreme Court refused to disqualify itself, arguing that a serious question was before it and "there is no other appellate tribunal to which under the law [the plaintiff] could go." Id. at 248. This doctrine of "necessity"that if the court whose impartiality is questioned is the only available tribunal to adjudicate 
discipline, especially the ordinary techniques for selection of trial and review boards, would justify such a presumption in most union discipline cases involving the political questions likely to arise under section 101 (a) (2).

While the conclusion of pervasive partiality within union tribunals reinforces the dilemma of no appropriate decision-maker as posed in Salzhandler, articulating the presumption of partiality may lead to a solution alternative to that suggested by the Second Circuit. That alternative may exist in the court's traditional competence and particular mandate under the act to guide unions along paths of procedural rectitude. If the primary obstacle to distinctions based upon the context of the conduct is that union tribunals are not sufficiently disinterested to be trusted to distinguish between punishable and protected speech-or between free assembly and dual-unionism, or any other balance of individual and institutional rights-then the solution is not to eradicate these necessary distinctions, but to insist that the unions provide tribunals sufficiently disinterested.

Congress was unequivocal in its mandate to the federal courts in section 101 (a) (5) to guarantee that no union discipline would be recognized in the absence of full and fair hearings. Because of the particular competency of courts in establishing and applying standards of adjudicative procedure, that assignment is completely appropriate. No agency is better suited to determine the limits of timely notice of hearing, or of the counsel necessary, or of the requirements of a written record. Identifying bias and insuring impartiality of tribunals within private organizations, an essential component of a full and fair hearing, may be a more complex problem than the adaptation of procedural safeguards to be employed by such tribunals. But by the application of a presumption of bias to ordinary union tribunals in cases involving political questions, courts could place upon the union the burden of constructing a judicial system which would insure that factional and other political pressures were not reflected in its decisions. So long as discretionary handling of the presumption leaves viable the possibility of a union's creating a workable and impartial judicial system, this approach may provide a successful resolution of the problem of no appropriate decision-maker suggested in Salzhandler. Agencies would exist within labor organizations themselves capable of distinguishing between members' rights and the institution's basic welfare; and, the impracticality of assigning the entire burden of such a process to the courts would be obviated.

The salutary effects of the procedural approach would not be limited to the litigants in a case in which that solution was applied. As an internal corrective,

issues which must be decided, that court must hear the case-has been echoed in state courts, (as has been the usual holding-that the challenged income taxes on judges' salaries are unconstitutional). Higer v. Hansen, 67 Idaho 45 (1946). See also Gordy v. Dennis, $176 \mathrm{Md} .106$ (1938). No such problems of necessity for a decision or necessity for a particular tribunal to make that decision arise in disqualifying a union tribunal for partiality. If the union is determined to discipline a member, it can provide an alternative judicial system which is free of the taint of personal bias, and thus should be required to do so. 
it might remedy more basic union ills of which any particular instance of abuse is but a symptom. By insisting upon full compliance with section 101 (a) (5) before even passing on any of the substantive issues involved in Title I, courts may be protecting the rights of members whose discipline they would never have reviewed, and may be insuring that other dissenters are not prosecuted at all. In fact, the entire range of rights guaranteed to members by Title I of the Act might be vindicated by a vigorous enforcement of section 101 (a) (5). An effective internal tribunal, while minimizing governmental intervention in internal union affairs, can serve as a continuous and self-applying check upon arbitrary executive conduct of the union's business.

Prescribing standards for disciplinary proceedings, including insistence upon impartial hearings is, of all the potential solutions available under Title I, the least encumbering of organized labor. Rather than forbidding unions the power to discipline in certain vital areas in which that power was apparently reserved to them, courts would require only that the disciplinary proceedings take a certain form. ${ }^{57}$ Certainly such a solution would interfere less in the internal ordering of unions than the imposition of substantive standards of the type suggested by the resolution reached in Salzhandler. Indeed, the courts can actually make more secure the unions' authority to protect themselves institutionally through discipline by candidly providing minimum procedural standards on which the unions can really rely. If the full protection of Title $I$ is to be guaranteed to members, and unions are still to be allowed to determine when their basic institutional functions are jeopardized by a member's conduct, then, as a New York court has stated, "[T]he tribunal ... [must not be] subject to the slightest suspicion as to its fairness. . . . If there was a problem as to how to provide an impartial appellate tribunal for these cases the burden of its solution was [the union's]." 58

Such a burden is not intolerable: it is quite within the powers of unions to develop a judiciary which can act with substantial impartiality in matters of internal dispute. Absolute impartiality can never be obtained, and minor aberrations of impartiality could probably be avoided only by withdrawing from unions the authority to establish their own disciplinary tribunals, by statutorily creating a court for intra-union disputes, ${ }^{59}$ or directing agents of the National Labor Relations Board to hear such cases. ${ }^{60}$ Yet Congress chose otherwise: seeking to vindicate both democracy in unions and pluralism in society, it

57. For an analysis of such a process, and its vindication of the individual's rights with the least encumbrance upon government, in this case civil government, see, Freund, The Supreme Court and Civil Liberties, 4 V AND. L. Rev. 533 (1951).

58. Madden v. Atkins, 4 App. Div. 2d 1, 18, 19, 162 N.Y.S.2d 576, 593 (1957), aff'd as modified, 4 N.Y.2d 283, 151 N.E.2d 73, 174 N.Y.S.2d 633 (1958).

59. See Hardman, Legislating Union Democracy, The New Leader, Dec. 2, 1957, pp. $3,7$.

60. Williams, The Political Liberties of Labor Union Members, 32 Texas L. Rev. 826,836 (1954). Another proposal would extend civil courts' present authority of judicial review to oversee more searchingly union disciplinary proceedings. Aaron \& Komaroff, Statutory Regulation of Internal Union Affairs-II, 44 ILI. L. REV. 631, 666-74 (1949). 
opted for union self-government and sought to make it responsible. ${ }^{61} \mathrm{By}$ recognizing and nourishing the development of a system of impartial internal adjudication, courts can help insure the integrity of unions and encourage their responsibility. The congressional choice suggests, rather than the attainment of any absolute goal, an effort toward a relative improvement in internal processes. Such an objective might be obtained even if only one of the tribunals within the union's judicial hierarchy was assuredly impartial, so long as its influence was felt throughout the union's judiciary. If the tribunal could be shown to be independent-free from the ordinary pressures of factional and personal interest-and if its decisions had substantial impact within and upon the union's disciplinary system, a court might justifiably conclude that the presumption of bias had been refuted.

Institutions are available which could satisfy such requirements. For instance, arbitrators, whether as original adjudicators of the charges against the member or as a reviewing body, could provide both the impartiality and the competence required by the function. ${ }^{62} \mathrm{~A}$ more interesting alternative was found by the United Automobile Workers, who in 1957 created a Public Review Board with jurisdiction to hear appeals from decisions of the union's ordinarily constituted trial boards. ${ }^{63}$ Functioning as a "supreme court for the union as to intra-union grievances,"64 and composed of seven "impartial persons of good public repute," 65 the Board operates independently of political pressures and yet within the normal process of the union's judicial system. ${ }^{66}$

61. See note 38 supra.

62. Williams, The Political Liberties of Labor Union Members, 32 TeXas L. Rev. 826, 836 ff. (1954); see also Tobias, A Proposal for Federal Regulation of Union Disciplinary Power, 9 LAB. J.L. 925, 932 ff. (1958).

63. UAW, Proceedings, 16th Constitutional Convention, 97-108 (1957). A full report on the first eighteen months of operation of the Board is published in the December 22, 1958 issue of the UAW newspaper, Solidarity, at 4-7. See also 39 L.R.R.M. 41 (1957), and Business Week, July 12, 1958, at 81-88.

The Upholsterers' International Union had instituted a Public Review Board in 1953, UIU General Laws, art. XXVI, $\S 6(b)$, but it has never been as effective as its UAW counterpart. See 34 L.R.R.M. 65 (1954).

64. Oberer, Voluntary Impartial Review of Labor: Some Reflections, 58 MicH. L. REv. 55, 57 (1959).

65. United Automobile Workers Constitution, art. XXXI, $\S 1$ and 2. The members of the Public Review Board are nominated by the international president of the union, ratified by the international executive board, and elected by the biennial convention. The seven members of the first Board suggest the standards of public morality which were to be applied, as well as the seriousness of the experiment: Rabbi Morris Adler, Congregation Shaarey Zadek, Detroit, Chairman; Magistrate J. A. Hanrahan, Essex County Magistrate's Court, Windsor, Ontario; Monsignor George Riggins, National Catholic Welfare Conference, Washington, D.C.; President Clark Kerr, University of California; Judge Wade McCree, Wayne County Circuit Court, Detroit; Bishop G. Bromley Oxnam, Methodist Church, Washington, D.C.; Dr. Edwin E. Witts, Professor Emeritus of Economics, University of Wisconsin.

66. For kinds of standards that impartial tribunals can apply, see Aaron \& Komaroff, Statutory Requisition of Internal Union Affairs-II, 44 IrL. L. REv. 631 (1949); Note, 
Evaluations ${ }^{67}$ of the impact of the UAW Public Review Board have emphasized the healthy restraint which the tribunal exercises upon the union hierarchy. ${ }^{68}$ Its existence has been conducive to more regular adherence to the union's constitution and to re-examination of union rules and procedures protecting internal due process. ${ }^{60}$ Officers have been more careful in dealing with dissent, and dissenters have shown a greater willingness to accept the judgments of the union judiciary. ${ }^{70}$ In short, the sense of responsible citizenship within the union has been noticeably fostered by the inclusion of an impartial tribunal within the disciplinary system. ${ }^{71}$

Courts may be justifiably skeptical in evaluating ostensibly impartial union tribunals. Unless judges are selected from outside the union's membership, it seems highly unlikely that the requisite independence will be possessed. Even where such selections are made, impartiality may prove a sham. Principles of selection which emphasize the community standing of the persons chosen and their non-involvement, directly or indirectly, in union politics should be favored; so should fixed terms, financial independence, and other characteristics traditionally associated with an independent bench. ${ }^{72}$ Moreover, there may

Public Review Boards: A Check on Union Disciplinary Power, 11 STAN. L. REv. 497 (1959); Cox, The Role of Laze in Preserving Union Democracy, 72 HARv. L. Rev. 609 (1959).

67. See Oberer, Voluntary Impartial Review of Labor: Some Reflections, $58 \mathrm{MICH}$ L. Rev. 55 (1959); Steiber, Oberer \& Harrington, Union Dearocracy and Public Review (Center for the Study of Democratic Institutions, 1960); Givens, Fedcral Protection of Employee Rights Within Trade Unions, 29 ForDEAMr L. Rev. 259, 293-301 (1960); Wellington, Union Democracy and Fair Representation: Federal Responsibility in a Federal System, 67 YALE L.J. 1327, 1349-51 (1958) ; Note, Public Review Boards: A Check on Union Disciplinary Power, 11 Stan. L. REv. 497 (1959).

68. For example, the UAW appeal boards, consisting of international officers, have been more demanding upon local tribunals, affirming only one-third as many decisions in the period immediately following the establishment of the Public Review Board as in the period immediately before. See Oberer, Voluntary Impartial Review of Labar: Some Reflections, 58 MICH. L. REv. 55, 81 (1959).

69. Ibid.

70. See Steiber, Oberer \& Harrington, Union Democracy and Public Review (Center for the Study of Democratic Institutions, 1960).

71. See Oberer, Voluntary Impartial Review of Labor: Some Reflections, $58 \mathrm{MICH}$. L. REv. 55 (1959). Archibald Cox has even proposed a procedure in which the Secretary of Labor would be authorized

... to issue periodic certificates exempting a union from governmental enforcement proceedings instituted by the NLRB upon a finding that the union had established an independent appeal board under the auspices of which a union member . . . would receive at least as great protection as he would before the NLRB or in a suit by the Secretary.

Cox, The Role of Lawe in Preserving Union Democracy, 72 HaRv. L. Rev. 609, 623 (1959). "This procedure would," Cox argued, "bring the cases much closer to the people affected. It would preserve a larger measure of informality, flexibility, and self-government. It would minimize government interference in internal union affairs." Ibid.

72. See Amrerican Civil Ltberties Union, A Labor Union "BIIL of Rights," Democracy in Labor Untons, The Kennedy-Ives Bili-Statements by the ACLU 
be reasons to inquire carefully into the effectiveness of one impartial body operating within a system of union discipline in which the other bodies are politically selected. The potential for impotence always exists in an umpire, whether arbitrator, public review board, or any other third party, employed by a powerful organization to adjudicate conflicts between it and a powerless member. On the one hand, an independent agency could succumb to forceful pressure; on the other, its results may be ignored in the massive inertia of a union traveling a familiar course. A court should determine the willingness of an impartial review board to reverse the decisions of lower tribunals and the impact of such reversals upon adjudicators, as well as the effect and respect given an independent adjudicator's decisions throughout an otherwise ordinarily constituted system.

To implement this suggestion for handling cases of controverted union discipline, courts should stress as a prior question whether the complaining union member had been given a full and fair hearing. An important part of that inquiry must be directed to the impartiality of the union's tribunals. Ordinarily the presumption of bias could be applied, subject to rebuttal, to determine whether an impartial hearing had been given the member. That an aggrieved member's case was adjudicated or reviewed by an independent and effective judicial body, whether arbitrator, public review board, or other similar agency should constitute a proper refutation of the presumption. Care must be taken not to encumber the flexibility of section 101 (a) (5) with unnecessary rigidity. Despite the presumption, a union should be permitted to prove that its institutional solution to the problem of an independent judiciary is as valid as arbitration or public review. Experimentation should be encouraged: a wide variety of acceptable agencies might be produced. Likewise a member should be allowed to prove that a tribunal, although so constituted as to seem im-

25 (1958). The American Civil Liberties Union has proposed, as a part of a general program to insure independent tribunals for intra-union disputes, that the judgment of an impartial review board be made enforceable in civil courts. Ibid. at 6-7. Some authorities, who advocate legislation empowering a supervisory federal agency to review intra-union grievances, have suggested that a strong presumption of validity or even finality be accorded by such an agency to decisions of voluntarily adopted impartial review boards which must meet certain standards. Oberer, Voluntary Impartial Review of Labor: Some Reflections, 58 MICH. L. REv. 55, 84-85 (1959). In that way the voluntary system could be protected against its inherent weakness by freeing impartial tribunals from exclusive dependence upon the good-will of union leadership. See Levitan, Government Regulation of Intcrnal Union Affairs Affecting the Right of Members, Report to House Committee on Education and Labor, 85th Cong., 2d Sess. 45-46 (Comm. Print, 1958). Under plans of this sort, impartial review boards, such as those of the UAW and UIU, would effectively operate as a substitute for official administrative review. This was essentially the plan for regulating union trusteeships contained in the original bill presented by Senator Kennedy before the 85th Congress: S. 3454, 85th Cong., 2d Sess. $\S 2044$ (1958), but eliminated in the Kennedy-Ives version: S. 3974, 85th Cong., 2d Sess. $\S 204$ (a), (b) (1958). The scheme is also similar to $\$ 10(\mathrm{k})$ of the Labor-Management Relations Act of 1947, which provides that the NLRB will not have jurisdiction to hear complaints on jurisdictional disputes if the parties submit their controversy to private settlement. 61 Stat. 149 (1947), 29 U.S.C. § 160(k) (1958). 
partial, in fact was biased. Furthermore, courts should not allow the impartiality of some intervening body to protect all errors in previous proceedings. The member ought to be permitted to show that in spite of the existence of an impartial body within the union's disciplinary system, he was nonetheless subjected to another tribunal which was particularly biased, or that at some point in the chain of proceedings he was denied one of the other essential elements of a full and fair hearing-that he was denied sufficient notice, or time adequately to prepare his case, or proper counsel. The experience and special competence of courts in this area should be applied in the adaptation of judicial standards to the context of labor organizations.

If the proceedings are found wanting, the discipline should then be invalidated without prejudice to the union's charges against the member. Otherwise, the requirements of section 101(a) (5) having been satisfied, a court may proceed to an inquiry as to whether the union rule under which the member was prosecuted is prohibited substantively by any section of the act, without the need for a trial de novo. Only the particularly judicial functions of prescribing procedural standards, statutory interpretation, and judicial review are necessary. While courts will not be completely freed from all responsibility for developing and applying substantive standards for reasonable disciplinary rules under the act, the greater part of this burden can be delegated to more competent decision-makers subject to the court's own review. Thus by insuring an independent judiciary for internal union disputes, courts can simultaneously enforce the mandate of Congress under section 101(a)(5) and protect both the unions' institutional integrity and the members' political rights as required under section 101(a) (2) without exceeding the proper limits of judicial participation in the process. 